\title{
GDY UMIERA DUCH, CZYLI O ŚMIERCI CIAŁA W AMERYKAŃSKIEJ POEZJI gejowsKiej Na PrZYKŁadZie wierszy Meskalina Allena Ginsberga ORAZ [SKARBIE CZY MNIE UDUSISZ: PODUSZKA W MYSZKI MICKEY] DOUGLASA A. Powella
}

\author{
Nie śmierć mnie niepokoi, lecz umieranie. \\ Michał z Montaigne \\ Przemysław Górecki, abakab@onet.eu \\ Uniwersytet im. Adama Mickiewicza w Poznaniu \\ Ul. Wieniawskiego 1, 61-712 Poznań

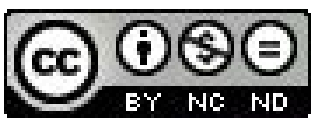

\begin{abstract}
Abstrakt
Komparatystyczna analiza dwóch współczesnych wierszy poezji amerykańskiej, uruchamiająca mechanizmy analizy językowej (porównywanie różnych przekładów i tekstów oryginalnych), kulturowej (rozwijanie wątków religijnych, filozoficznych, kontrkulturowych - bitnicy, kultura gejowska USA), prowadzonej w perspektywie tanatologicznej i genderowej. Próba ukazania zakorzenienia tej poezji w tradycji liryki amerykańskiej i przedstawienia nowatorstwa tak ujmowanej problematyki. Symultaniczna interpretacja akcentuje miejsca wspólne podmiotów lirycznych oraz tropi pozornie marginalne sygnały kulturowe.

Słowa kluczowe: poezja amerykańska, homotekstualność, queer, analiza genderowa, analiza językowa, analiza kulturowa, komparatystyka, biografizm, Beat Generation, AIDS
\end{abstract}

When the spirit dies, or the death of body in contemporary American gay poetry. The case of two poems: Mescaline by Allen Ginsberg and [darling can you kill me: with your mickeymouse pillows] by Douglas A. Powell

\section{Abstract}

The paper is a comparative analysis of two contemporary American poems which activates mechanisms of linguistic (comparing different translations and confronting them with the source texts), and cultural (elaborating on the religious, philosophical and countercultural issues concerning the Beat Generation and gay culture in the US) analyses from a thanatological and gender perspective. It is an attempt to show the affiliations between these literary works and the tradition of American poetry as well as their novelty. Simultaneous interpretation highlights loci communes of lyrical subjects and discerns seemingly marginal cultural signs.

Keywords: American poetry, homotextuality, queer, gender analyse, linguistic analyse, cultural analyse, comparative literature, biographism, Beat Generation, AIDS

Punktem wyjścia analizy wierszy jest kontekstualizacja filozoficzna oraz teza o podobieństwie psychologicznym ich podmiotów i zbieżności sytuacji lirycznych. Szczegółową analizę utworu Meskalina (interpretację sytuacji podmiotu, tropów kulturowych i strony językowej) poprzedza akapit poświęcony homotekstualności jako sposobami kodowania tekstu. Druga fragment analitycznej części pracy poświęcony jest utworowi [skarbie czy mnie udusisz: poduszka w myszki mickey] oraz związanym z nim kwestiom językowym, kulturowym i artystycznym. Zakończenie wpisuje rozważania w kontekst tanatologiczny.

Interdyscyplinarna perspektywa z jakiej prowadzona jest analiza literacka i kulturoznawcza ma na celu ukazanie istotnego oraz "naturalnego" związku między tradycją literacką a pozostającą do niej w relacji spadkobierczej wspótczesną poezja; ukazanie nieodzowności kontekstu filozoficznego przy interpretacji treści zakorzenionych w określonych szkołach i prądach myślenia. Poza badaczami i badaczkami kultury i literatury - a więc zarówno historykami zajmującymi się zwłaszcza historią kontrkultury, jak filologami o specjalizacji translatorskiej - praca ma w założeniu mieć wartość 
poznawczą także dla przedstawicieli i przedstawicielek nauk psychologicznych, ze względu na bezdyskusyjną rangę tej dziedziny wiedzy w rozważaniach oraz traktowanie jej jako narzędzia analizy równoprawnego z pozostałymi.

\section{ŚMIERĆ JAKO NIEŚMIERTELNOŚĆ, JA JAKO INNY}

W pochodzących $z$ lat siedemdziesiątych XX w. studiach tanatologicznych francuski psychoanalityk Michel de M'Uzan stworzył formułę „A.j.j.m.” (co stanowi skrót frazy „A jeśli jestem martwy...”), proponując jąjako analogon słynnego dopisku z kart Tołstojowskiego dziennika: ,j.j.z.z." (,jeśli będę żył”) ${ }^{1}$. Refleksja taka miałaby jawić sięjako jednostkowy fantazmat nieśmiertelności, w rzeczywistości zaś być kostiumem dla znanej prawdy; myśl ta podaje w wątpliwość realność egzystencji "tu i teraz", implikuje kolejne pytanie: czy można jednocześnie żyć i być martwym? Jednym z najprostszych i jednocześnie najbardziej skutecznych rozwiązań tego problemu „istnienia i nieistnienia" wydaje się być wprowadzenie figury sobowtóra - nie jest to jednak klasyczny Doppelgänger, który znaczyć nie może nic innego jak konstrukt zbudowany z cech sobowtóra i alter ego. To „inny" (M. de M’Uzan stosuje metaforę lustra, według prawideł której „innym” jest odbicie lustrzane wypowiadającego kwestię „A.j.j.m.”), będący czymś na kształt sobowtóra pozbawionego akcydentalnych - niewspółdzielonych $\mathrm{Z}$ "pierwowzorem" - cech, dzięki czemu jego odrębność i indywidualność (tak niebezpieczna z punktu widzenia ,„ja") zostaje mu odebrana. Pojmować to można jako akt pozornej interioryzacji „innego" (w obronie przed multiplikacją własnej tożsamości?), z założeniem przeszczepienia jego jaźni na bezosobowy do tej pory twór zwany sobowtórem.

Poetyckich obrazów takiej konfrontacji dostarcza poezja Allena Ginsberga z niebagatelnym natężeniem i, zwłaszcza od pewnego momentu jego literackiej aktywności, z dużą częstotliwością. Wraz z nasyceniem się materii poetyckiej duchowego mecenasa bitników wątkami związanymi ze śmiercią matki, Naomi Ginsberg (czerwiec 1956, a więcjeszcze cztery miesiące przed publikacją Skowytu), nastąpiło swego rodzaju przesycenie tej poezji wizjami narkotycznymi²; pojawiła się jednak pewna aktualizacja sposobu formowania rzeczywistości wizyjnej. Obraz fizycznego cierpienia połączonego z metafizycznym bólem zostaje wzbogacony o stygmat śmiertelności ciała, który wyraża się na powierzchni dociekań o podłożu eschatologicznym. Nadejść ma dopiero era wielkich podróży Ginsberga do Indii, Japonii czy Tajlandii, a więc czas zgłębiania tajników Dharmy czy krysznaizmu. Tworzeniu poematu Kadysz, dedykowanego pamięci zmarłej matki, towarzyszyła eksploracja innych obszarów kulturowych - korzeni żydowskich (inna rzecz, że z wyraźnym i charakterystycznym dla poezji bitników sfunkcjonalizowaniem i zbanalizowaniem przeżycia mistycznego); otworzyła ona przed poetą perspektywę rozważań dotykających kwestii transcendencji. Wymownym przykładem realizacji tego „nowego kierunku" jest cały zbiór Kadysz i inne wiersze (wydany w kwietniu 1961). Znajdujący się w nim utwór Meskalina wprowadza czytelnika do mieszkania Ginsberga, który doświadcza znajomej sytuacji:

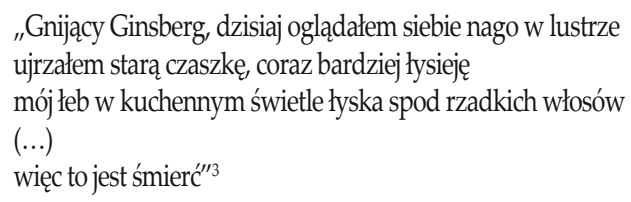

Tak przedstawiona scena jest doskonałą realizacją formuły „A.j.j.m.” - Gnijacy Ginsberg widząc w lustrze „innego” (dystans dobitnie podkreślony poprzez wyindywidualizowanie i odrębność , ,ja" mówiącego od „Gnijącego Ginsberga"4) dokonuje rozpoznania: to śmierć. Postawienie znaku równości między życiem (podmioti jednocześnie przedmiot refleksji jest przecież wśród żywych i jako żywy obserwuje się w lustrze) i śmiercią (fraza „więc to jest śmierć" nie pozostawia złudzeń co do wniosków wypowiadającego) zdaje się być odpowiedzią na postawione na początku artykułu pytanie: można jednocześnie żyć i być martwym. Z pewnością jest to możliwe w świadomości „gnijącego" - a trzeba wspomnieć, że poeta Meskalinę napisał mając lat zaledwie trzydzieści trzy (wiek znaczący przecież w kulturze!). To Ginsberg „kadyszowy”, jak określa go Piotr Sommer: Ginsberg „,od demonstracyjnych kłopotów z tożsamościa, namolny tułacz pośród

M. de M'Uzan, A.j.j.m., [w:] S. Rosiek (oprac.), Wymiary śmierci, Gdańsk 2002, s. 65-76.

2 Ważną cezurą jest tutaj listopad roku 1960, poeta poznaje wtedy harwardzkiego profesora psychologii Timothy'ego Leary'ego, który wprowadza go w tajniki działania grzybów psylocybinowych.

3 Wiersz Mescaline (rok 1959) podaję w thumaczeniu Grzegorza Musiała. Zob. A. Ginsberg, Meskalina, [w:] Tenże, Kadysz i inne wiersze, Bydgoszcz 1992, s. $127-131$

4 W oryginalnym brzmieniu: ,Rotting Ginsberg, I stared in the mirror naked today”. Można zdanie to odczytywać poprzez odwrócenie formuły identyfikacyjnej - „Ja, Gnijący Ginsberg” lub nawet jako zwrot do Gnijącego Ginsberga - pozwala na tę interpretację niejednoznaczność wyrażenia, interpunkcja. 
płci, poglądów, sposobów bycia" ${ }^{\prime \prime}$. W utworze dokonało się zespolenie wszystkich wątków właściwych dla tego etapu jego twórczości; obecność narkotyku sygnalizowana jest już w tytule, pojawia się intrygujące nawiązanie do kwestii judaistycznych, wszechobecne poczucie płciowego niedookreślenia - osnowę stanowi zatem kwestia, którą należy w szerokim pojęciu nazwać tanatologiczną.

Interesująco wypada zestawienie Meskaliny z wierszem jednego z najważniejszych amerykańskich poetów swojego pokolenia, Douglasa. A. Powella, urodzonego w roku 1963, a więc cztery lata po powstaniu ginsbergowego wiersza. Jego [skarbie czy mnie udusisz: poduszka w myszki mickey] ostentacyjnie i bezkompromisowo wprowadza zagadnienie tanatologii w czuły rejestr śmiałych domniemań:

\begin{abstract}
„skarbie czy mnie udusisz: poduszką w myszki mickey
kiedy już zmizernieję. i czy twoje zastrzyki

skutecznie mnie uśpią: kiedy niemal nie będzie mnie w ogóle

będę strzępem krztą okruchem byle drobiną spętaną bólem" ${ }^{\prime \prime}$
\end{abstract}

\title{
HOMOTEKSTUALNA RAMA INTERPRETACYJNA
}

Przed analizą kwestii usytuowania podmiotu względem sygnalizowanych przy okazji Meskaliny płaszczyzn, konieczne jest wyciągnięcie z twórczości Ginsberga i Powella wspólnego mianownika. Jest nim homotekstualność poezji obu twórców. W artykule Tomasza Kitlińskiego i Pawła Leszkowicza Homotekstualność: homoseksualność i twoórczość, zawarta jest próba definicji tej właściwości, wedle której należy ją rozumiećjako obecność i ekspresję (w tekście) tej formy seksualności, która wykracza poza heteronormatywność. Parafrazując utworzone przez Monique Wittig pojęcie, można stwierdzić, że autorzy homotekstualnych utworów zawierają z czytelnikami pewien niepisany „,homoseksualny kontrakt"8. Pełniejsze wyobrażenie zyskać można jednak dopiero dokonując kolejnej parafrazy - homotekstualność zakłada już w punkcie wyjścia „obowiązkowy homoseksualizm”, , definiujący bardzo wiele aspektów literackiej materii - od specyfiki narracji i niedopowiedzeń, po stosunki między bohaterami. Wyznaczniki nieheteronormatywnego dyskursu poetyckiego uwidaczniają się w charakterystycznym kodzie tekstowym, strukturze tożsamościowej podmiotów lirycznych i, co istotne, twórców, którzy wpisują się w szeroko pojmowany homoseksualny nurt współczesnej poezji amerykańskiej. Warto tu przywołać jedną tylko tezę ze wspomnianej rozprawy T. Kitlińskiego i P. Leszkowicza: homoseksualność jest figurą tekstualności. Wiadomym i oczywistym staje się takie ujęcie kwestii, jeśli wziąć pod uwagę, iż tekstualność pojmowana jest przez autorów artykułu jako warunek konieczny do wykroczenia homoseksualności poza reżim formy heteroseksualnej. To przydatne i atrakcyjne ustalenia z punktu widzenia odbiorcy zestawionych przez autora artykułu wierszy, nie determinujące jednak całkowicie sposobu interpretacji.

Rzeczą niepodlegającą wątpliwościom jest fakt, iż oba utwory zostały zawłaszczone przez dyskurs nieheteronormatywny (lub wręcz odwrotnie: to one „wchłonęły” ów dyskurs). Istnieje jednak różnica pomiędzy Ginsbergiem a Powellem. O ile drugiego z tych autorów uznaje się za jednego z najistotniejszych przedstawicieli amerykańskiej poezji gejowskiej, o tyle poetyckie indywiduum Ginsberga jest przez homotekstualność zdeterminowane w nie większym stopniu niż przez wizyjność, narkotyczność, pacyfizm, anarchizm, ideologię „,anielogłowych hipstersów” czy swoisty kolaż religijny, składający się z odłamków judaizmu, buddyzmu i krysznaizmu. Jego wiersze, dzięki ich tendencji do poetyckiego ogarniania totalności doświadczenia egzystencjalnego (przejawiającej się w zapisie absolutnie wszystkich składników przeżywanej codzienności), tworzą pewną subiektywną syntezę rzeczywistości. Utwory Powella mają inny charakterystyczny rys, cechują się subtelną poetyką wyznania, specyficznym skonceptualizowaniem; zazwyczaj nie roszczą sobie prawa do tak spektakularnego i dalekosiężnego oglądu tego, co doświadczane. Wnikliwośćliterackiego spojrzenia Powella ukierunkowana jest, ponowniejak u Ginsberga, introspektywnie, cechuje sięjednak większą „,zdolnością skupiającą” skojarzeń, jej zasięg asocjacyjny jest szeroki, lecz nie rządzi się swoimi prawami w tak zuchwały sposób.

5 P. Sommer, Ten staroświecki Allen Ginsberg, [w:] A. Ginsberg, Znajomi z tego świata, P. Sommer (oprac.), Kraków 1993, s. 93.

6 Wiersz [darling can you kill me: with your mickeymouse pillows] podaję w thumaczeniu Michała Tabaczyńskiego. Zob. D. A. Powell, [skarbie czy mnie udusisz: poduszką w myszki mickey], [w:] M. Tabaczyński (red.), Parada równości. Antologia wspótczesnej amerykańskiej poezji gejowskiej i lesbijskiej, Kraków 2005, s. 147.

7 T. Kitliński, P. Leszkowicz, Homotekstualność: homoseksualność i twórczość, „Sekcja” 2005, nr 12.

8 Autorka sformułowania ,kontrakt heteroseksualny".

9 Parafraza teorii „obowiązkowej heteroseksualności” Adrienne Rich. Zob. A. Rich, Compulsory Heterosexuality and Lesbian Existence, "Journal of Women's History" 2003, s. 11-48. 
Wspólnym mianownikiem obu utworów nie może być jedynie homotekstualność - wówczas inny byłby tytuł studium, inny profil dociekań. Oto, jak mają się do siebie sytuacje liryczne wierszy: stwierdzając ogólnie, każdy z nich przedstawia człowieka w obliczu antycypacji własnej śmierci. Meskalina to liryczny monolog oglądającego się w lustrze, z niemałą dozą weryzmu opisanego, gnijącego Ginsberga, który dokonuje chaotycznej i bardzo emocjonalnej rewizji swojej teraźniejszości i przeszłości, czyniąc z tych dwóch płaszczyzn czasowych tło dla uniwersalnych rozważań dotyczących przyszłości i pragnienia poznania pośmiertnego losu człowieka. Podmiotem wiersza [skarbie czy mnie udusisz: poduszka w myszki mickey] jest mężczyzna nieujawniony i nieokreślony, co do wieku, stanu zdrowia i wyglądu. Tekst tworzą zawieszone nad ukochanym pytania o to, czy ten pomoże mu w umieraniu (pojmowanym jako ucieczka od cierpienia), gdy stanie się on organizmem toczonym chorobą? Dramatyzm budują mniej lub bardziej zawoalowane sugestie, by ukochany jednak umożliwił mu odejście, ponieważ będzie ono najlepszym rozwiązaniem dla obu stron. Aby zbadać stopień, w jakim pokrywają się postawy, poglądy i cechy osobowe gnijącego Ginsberga i powellowskiego podmiotu, konieczna jest bardziej szczegółowa analiza ich słów. Zatem - z czego poskładane są jednostki, które określają się jako stojące na progu rozkładu?

\title{
RZECZYWISTOŚĆ PSYCHICZNA GNIJĄCEGO GINSBERGA
}

„Lustrzane rozpoznanie"10 gnijącego Ginsberga wpisujące się w nurt myślenia „A.j.j.m." cechuje się dużą samoświadomością - poeta wie, że indywiduum dostrzeżone przez niego w odbiciu to on w całej swej istocie ${ }^{11}$. Dalszy wywód prowadzi już we własnym imieniu (manifestuje to w drugim wersie, mówiąc: „coraz bardziej łysieję" - a przecież chcąc być konsekwentnym, powinien wyznać, że to gnijący Ginsberg łysieje), wplatając czasem tylko niespodziewanie figurę swojego rozkładającego się wcielenia. Takie odpodmiotowienie i obiektywizacja siebie samego może być mechanizmem obrony wynikającym ze strachu i niemożliwości wyobrażenia sobie własnej śmierci; perspektywa ,,ja” jako „,on” pozwala oddalić od siebie wizję umierania. Kontestacja: „więc to jest śmierć” umożliwia natomiast określenie radykalizmu podmiotu w kwestii kategoryzowania tak absolutnych zjawisk. Na tym poziomie diagnozy, śmierć jest dla niego tożsama z łysiejącą czaszka, rzadkimi włosami i hiperbolicznie określonym stanem „gnicia”. Nie ma bowiem sygnałów świadczących o dostrzeżeniu agonii tej sfery człowieczej, która nie wiąże się z jej cielesnościa, z jej, operując filozoficzną kategorią Jolanty Brach-Czainy, mięsnościa. Jestestwo Ginsberga zdaje się w tym momencie ograniczać do owej mięsności, tożsamość jest określana ciałem ${ }^{12}$.

Kontrastem do tak zobrazowanej „śmierci” jest wszystko to, co podmiot Meskaliny wymienia, niby niezobowiązująco, niby dla dopełnienia poetyckości sceny. Zupełnie jakby pragnął odwrócić swoją uwagę od własnego "gnicia", zwraca ją na kota, który snuje się po pracowni, miauczy i bazgrze ${ }^{13}$, na muzykę sączącą się z gramofonu, na pożółkłą fotografię wiszącą na ścianie. To jednak tylko pozorna naiwność i beztroska. Nie bez znaczenia są wszystkie antroponimy, które wylicza poeta:

\author{
„Boito śpiewa z gramofonu pradawną pieśń aniołów \\ brązowa fotografia z popiersiem Antinousa patrzy nieruchomo ze ściany \\ światło wytryska z subtelnej dłoni Boga mknie w dół drewniany gołąb \\ ku spoczywającej dziewicy \\ wszechświat Beato Angelico"14
}

$10 \mathrm{~W}$ świetle dalszych rozważá na temat symboli kulturowych, ciekawa i bardzo istotna staje się uwaga Jana Białostockiego sytuująca się w obrębie rozważań ,lustro a przemijanie”: „Pod koniec XVI wieku, wraz z ciaglym wzbogacaniem repertuaru ikonograficznego i emblematycznego, zasób motywów związanych z ideami znikomości i przemijania jest coraz bogatszy. Lustro, ukazujące złudny obraz rzeczywistości, odgrywa tu poważną rolę, łącząc się zresztą z tematem próżności ludzkiej (Tycjan)”. Zob. J. Białostocki, Pté śmierci, M. Ogonowska (red.), Gdańsk 2007, s. 66.

11 Innemu thumaczowi Meskaliny, Bogdanowi Baranowi, nie udało się tego wyraziście oddać. Frazę, „I stared in the mirror naked today” przethumaczył jako ,patrzyłem dziś w lustro nagi”, nie kładąc nacisku na ujednoznacznienie gnijącego Ginsberga z tym, który „patrzył w lustro”. Taki nacisk położył G. Musiał, używając nie pozostawiającej złudzeń konstrukcji z zaimkiem zwrotnym (,,ogląałaem siebie nago w lustrze”).

12 Jolanta Brach-Czaina jednak stawia w jednej ze swoich prac tezę, że mięsność odkrywa przed człowiekiem metafizyczną perspektywę istnienia: „Warto przypomnieć, że w pierwszej chwili kontakt z mięsnością zdawał się grozić nam spłaszczeniem egzystencji; takie fałszywe wrażenie można było wynieść ze świadomego obcowania z mięsnościa. Zdawało się, że nie obiecuje ona niczego poza uwięzieniem nas w płaskiej materii. A tymczasem to, co braliśmy za unieruchamiające wyobraźnię wypłaszczenie, okazało się bliskie metafizycznej nadziei”. Zob. J. Brach-Czaina, Metafizyka mięsa, [w:] M. Szpakowska (red.), Antropologia ciała, Warszawa 2008, s. 87.

13 W oryginale: ,the cat's gone mad and scraowls around the floor" - neologizm "scraowls" powstały z połączenia wyrazów "scrawls" (bazgrze) i $\square$ miaows" (miauczy), nie do przetlumaczenia dla żadnego z tlumaczy Meskaliny (B. Baran wybiera wersję ,miauczy”, zaś G. Musiał, bezpiecznie, podaje oba wyrazy).

14 A. Ginsberg, Meskalina..., dz. cyt., s. 127-131. 
Boito, Antinous, Beato Angelico - wszystkie te nazwiska są niezwykle istotne. „Pradawna pieśń aniołów” to z pewnością Chór Aniotów z Mefistofelesa, opery Arrigo Boito. Utwór ten posiłkował się legendą Fausta, co wydaje się być wymownym sygnałem. Dlaczego gnijacy Ginsberg, który właśnie dostrzega swą śmiertelność i przemijanie, słucha akurat pieśni z dzieła o Fauście - archetypie jednostki pragnącej zatrzymać czas? Również, dlaczego na ścianie wisi fotografia Antinousa - greckiego herosa, kochanka cesarza Publiusza Eliusza Hadriana oraz, przede wszystkim, uosobienia i wzoru młodzieńczego piękna? I, wreszcie, dlaczego dopełnieniem osobliwej kolekcji ideałów jest obraz Fra Angelico Ottarza Zwiastowania? - bo to właśnie scena z tego klasycznego (apogeum renesansu - rok 1426) dzieła przedstawiona została we fragmencie o wytryskającym z Boskiej dłoni świetle ${ }^{15}$. Kwestia homoestetyki i właściwego jej kultu młodości, ciała i piękna (nader dosłownie pojmowanego) nie jest wyczerpującą odpowiedzią․ Komponując panoramę zbudowaną z wizerunków piękna, z przedmiotów przedstawiających kwintesencję młodości ${ }^{17}$, otaczając się atrybutami świata, w którym istnieje tylko doskonałość formy i kształtu, stary i łysiejący nieszczęśliwiec tworzy coś na kształt symulakrum rzeczywistości istniejącej poza obszarami wpływów brzydoty, starości, rozkładu ${ }^{18}$. Taka psychologiczna ucieczka nie okazuje sięjednak zdolna do ugaszenia wielkiego wewnętrznego niepokoju ${ }^{19}$. Idąc tropem podjętym przez Judith Butler w Uwikłanych wo pteć, można powiedzieć, że jego stan jest wynikiem głębokiej niezgody na utratę (młodości?): „Ujmując tożsamość kulturowej płci jako strukturę melancholijna, trzeba też przyjać, że utożsamienie zachodzi na drodze inkorporaciji. (...) Tożsamość kulturowej płci powstaje poprzez niezgodę na stratę, która zostaje pogrzebana w ciele, a to w końcu definiuje, co jest ciałem żywym, a co martwym²0.

Nakreśliwszy panoramę swojego codziennego otoczenia, przechodzi Ginsberg dość niespodziewanie do rozważań dotykających kwestii transcendencji.

"Co będzie jeśli gong śmierci uderzy w łeb gnijącego ginsberga

w jaki wejdę wszechświat" 21

Wyczuwalna jest zmiana postawy, spokornienie ego i zdecydowana utrata pewności siebie; gnijacy Ginsberg pojawia się w zapisie nie uwzględniającym wielkich liter, cały ten sztafaż mozolnie układany przed chwilą przestaje odgrywać jakąkolwiek rolę -jest tylko śmierć, dostrzeżona i wypowiedziana wielokrotnie, artykułowana najpewniej w tempie mantrycznym. Pojawia się jednak ktoś większy mocą od Ginsberga a nawet od owej śmierci - pan „dalszy, niż okiem sięga”, poeta: Bóg. Jego obecność, nie wiadomo, czy wyczuwana, czy teoretycznie założona, staje się pretekstem do szlachetnych pytań i konstatacji: „ta droga musi dokądś prowadzič”. Częste w obrębie tej cząstki konfesji powtórzenia („,śmierć śmierć śmierć śmierć śmierć kot śpi”, czy „dzięki Bogu/ dzięki komu/ dzięki komu/ dzięki Tobie”) oddają swoiste zapętlenie myśli, ich chaotyczną szamotaninęi gonitwę; zupełnie tak, jakby kumulowały się one w świadomości od dłuższego czasu, skutecznie tamowane i zagłuszane owym „pięknym sztafażem”, teraz zaś mogły wreszcie, dzięki sprzyjającym okolicznościom (uzmysłowienie sobie własnego przemijania? zażycie meskaliny?) ze zdwojoną siłą i prędkościa, znaleźć ujścieie

15 Interesujący jest koncept z „drewnianym gołębiem”. Obraz Angelica przedstawia rzeczywiście gołębia zsyłanego przez Boską dłoń; malutki gołąb (sam w sobie będący symbolem Ducha Świętego) znajdujący się w Boskim promieniu nad głową archanioła Gabriela nie zdradza znamion drewnianej formy. Jaki efekt chciał osiaggnąc Ginsberg uznając go właśnie takim? Być może pomysł ten zrodził się z inspiracji opowiadaniem Virginii Woolf Poniedziatek lub wtorekpojawiają się tam gruchające z zadowoleniem (lub odzywające się złowieszczo w ciszy) drewniane gołębie.

16 Przy okazji warto zwrócić uwagę na drugą stronę homoestetycznego medalu: kult młodości, ciała i piękna nieuchronnie implikuje strach przed starością i umieraniem. Zbliża to bardzo do siebie zagadnienia homoestetyki i nauki o śmierci, thumacząc ważkość motywu tanatologicznego.

$17 \mathrm{~W}$ początkach europejskiej ikonografii związanej ze śmiercią, motyw młodzieńców (w tym greckiego Tanatosa) był równie rozpowszechniony jak wizerunek mężczyzn dojrzałych. Może to świadczyć o częściowym utożsamieniu śmierci z młodością, a przynajmniej o silnym związku obu zjawisk.

18 Inaczej spojrzał na zagadnienie piękna Robinson Jeffers, poeta nazwany „Whitmanem ludzkiej niegodziwości”, w wierszu Napis na kamieniu nagrobnym. Podmiot liryczny, który kreuje sytuację swojej śmierci, wyznaje: „Kiedy byłem ludzki/ Podziwiałem piękno, ale teraz jestem jego częścią”. W przeciwieństwie do R. Jeffersa, Ginsberg zdaje się nie dostrzegać horacjańskiego związku pomiędzy śmiercią a nobilitacją człowieka do rangi nieśmiertelnego piękna. Zob. R. Jeffers, Napis na kamieniu nagrobnym, A. Międzyrzecki (thum.), [w:] J. Hartwig, A. Międzyrzecki (oprac.), ...opiewam nowoczesnego człowieka. Antologia poezji amerykańskiej, Warszawa 1992, s. 100.

19 Warto porównać to wyobrażenie z wierszem Gregory'ego Corso Wiosna Boticellego, który w całości zbudowany został z dość przewrotnych wspomnień o renesansowych mistrzach. Nie bez znaczenia jest tu fakt, że Ginsberg poznał G. Corso w 1950 i poeci stali się bliskimi przyjaciótmi, pozostali również w orbicie wzajemnych wpływów artystycznych.

20 J. Butler, Uwikłani w płeć. Feminizm i polityka tożsamości, Warszawa 2008, s. 149. W rozdziale Freud imelancholia płci J. Butler w sposób interesujący z punktu widzenia tej interpretacji analizuje różnice i związki melancholii i żałoby.

21 A. Ginsberg, Meskalina..., dz. cyt., s. 127-131.

22 Wrażenie szybkiego tempa budowane przez częstotliwość powtórzeń zdaje się wiernie odwzorowywać tok myślenia wypowiadającego, daje jednocześnie poczucie namacalności jego procesu myślenia, tzw. dziania się „na żywo”. Ciekawym zabiegiem jest nagłe wstrzymanie ,pędzącego wersu”, niejako retardacja, we fragmencie: „śmierć śmierć śmierć śmierć śmierć kot śpi”.

OGRODY NAUK I SZTUK NR 2014 (4) 
Intrygująca wydaje się ponowna zmiana perspektywy - bardzo szybko pada wyznanie: „gnijący ginsberg/ więc niech się psuje (...)". Czym można wytłumaczyć ten powrót do dychotomicznego pojmowania siebie samego? Zamiast stwierdzić „niech się psuję", czego wymagałaby konsekwencja utożsamiania się z gnijacym Ginsbergiem, tutaj podmiot wyraźnie dystansuje się od rozkładającego się ciała. Czy można poczytywać ten gest za przejaw duchowego rozwoju, awansu do rangi bardziej wtajemniczonego? Za tym przemawiałyby dalsze wersy, które sugeruja, że cała ta droga (dosyćbrutalnie scharakteryzowana) ${ }^{23}$ jest $w$ istocie szlakiem do nie wiadomo czego; świadomość celowości zdaje się jednak uświęcać motywację.

TROPY, NAWIAZZANIA, DUCHOWE SPADKOBIERSTWO

Co typowe dla poezji Ginsberga, refleksja stanowi doraźne źródło innej refleksji; w tym przypadku ledwie zasygnalizowana kwestia rodzicielstwa staje się przyczynkiem do podjęcia tematu ustatkowania i poruszenia kwestii należącej do najbardziej osobistego obszaru - wspomnień związanych z Naomi.

\author{
„Tak, powinienem być porządny, powinienem się ożenić \\ zrozumieć wreszcie o co w tym wszystkim chodzi \\ ale nie mogę znieść tych kobiet wokół mnie \\ zapachu Naomi \\ brr, przyczepił się do mnie ten znajomy gnijący ginsberg ${ }^{24}$ \\ już nawet dość mam chłopaków ${ }^{\prime 25}$
}

Obraz pozornego zblazowania to w rzeczywistości sygnał głębzzego problemu. Sfery niegdyś bliskie i istotne, teraz jawią się jako źródło frustracji i zniechęcenia. To wyliczenie kolejnych obszarów zwątpienia, utwór staje się swego rodzaju dokumentem powolnego wypalenia wewnętrznego Ginsberga. Ton rozgoryczenia, w jakim wypowiada się o znużeniu i obrzydzeniu seksualną stroną życia, przewidywalnością i powtarzalnością procesów, także kopulacyjnych („zrobić bachora i won") musi nasuwać skojarzenia z wierszem Jacka Kerouaca Chorus $212^{26}$ i pojawiającym się w nim „mięsistym kołem zniewolenia":

\author{
„Mięsiste koło poczęcia \\ Obraca się konwulsyjnie \\ Wyrzucając w próżnię stworzenia ludzkie \\ (...) \\ Nieszczęsny! Chciałbym się uwolnić \\ Od tego mięsistego koła zniewolenia \\ I bezpiecznie być trupem w niebiosach ${ }^{\prime 27}$
}

To silnie buddyjski trop-jego pejoratywne nacechowanie budzi skojarzenia z nieświadomym (wynikającym z trucizn pożądań, czy innych małostkowych emocji) tkwieniem w krążącym kole życia - bez duchowej świadomości najwyższego stopnia.

J. Kerouac wyraził w sposób bardzo dosadny pragnienia, które najprawdopodobniej podziela podmiot Meskaliny. Uwagę zwraca przede wszystkim pełne żalu nad sobą zakończenie wiersza, $\mathrm{w}$ którym zawiera się cały ból konieczności życia wpisanego w nieustanne działanie mięsistego koła; czy i gnijącemu Ginsbergowi bliskie jest pragnienie bycia bezpiecz-

23 „droga/ przez gnijący gówniany rynsztok, przez orgie Angelica/ Pi, pi, zrobić bachora i won” - w oryginale: „the path/ thru the rotting ship dump, thru the Angelico orgies/ Beep, emit a burst of babe and begone”. Mniej dosadnie, a bardziej wiernie przetlumaczył ten fragment B. Baran: ,droga/ przez składowisko gnijących okrętów, przez orgie Angelico/ piip, wydaj dziecię i odejdź”; żaden z thumaczy nie oddał jednak aliteracyjnego charakteru tekstu oryginalnego, a przez to - gorączkowego tonu rozgoryczenia.

24 Fragment ,ale nie mogę znieść tych kobiet wokół mnie/ zapachu Naomi/ brr, przyczepił się do mnie ten znajomy gnijący ginsberg” buduje sensualną poetykę utworu. Ciekawy i dosadny jest koncept z zestawieniem obok siebie ,zapachu Naomi” z , ,onijącym ginsbergiem” (budzacym skojarzenia z zapachem wydzielanym przez procesy gnilne) i onomatopeiczną eksklamacją „,brr” wyrażającą zniesmaczenie - potęguje efekt, jakim jest nałożenie się na siebie dwóch zapachów.

25 A. Ginsberg, Meskalina..., dz. cyt., s. 127-131.

26 J. Kerouac, Chorus 211, [w:] J. Hartwig, A. Międzyrzecki (oprac.), ...opiewam nowoczesnego czlowieka ..., dz. cyt., s. 271.

27 A. Ginsberg, Meskalina..., dz. cyt., s. 127-131. 
nym „,trupem w niebiosach"? W Meskalinie poukrywał kilka odpowiedzi na to pytanie ${ }^{28}$.

We fragmencie: „Bezkresne morza przepływaja/ strumień czasu” można dostrzec pewne symptomy wymagania linearności od czasu - w końcu „droga musi dokądś prowadzič", tymczasem ta przepływa strumieniem następstw, nie przybliżając do celu wędrówki. Koncepcja ta byłaby niewątpliwie silnie judaistycznym tropem, co nie wydaje się przecież być zaskakujące.

W budowie utworu dostrzec można pewien paralelizm. Tak jak w przypadku dwóch pierwszych strofoid, również w dwóch kolejnych widać podobieństwo: jedna składa się w znacznej mierze z refleksji skonkretyzowanych na podłożu osobistych wspomnień, doświadczeń i okoliczności, druga zaś dotyka rejestrów bardziej zuniwersalizowanych, podejmuje polemikę dotykając kwestii Boga i metafizyki. Konstruowanie siebie nie jest możliwe bez sytuowania „ja” wobec transcendencji i określenia jego relacji z nią. Zastanawia jednak kwestia kolejności - rozważania w Meskalinie sprawiają wrażenie trwale ze sobą powiązanych, każde wyznanie indywidualne jest pretekstem do uruchomienia uniwersalnego układu odniesień. Hans-Christian Kirsch w powieści biograficznej poświęconej bitnikom sugeruje, że na kierunek refleksji Ginsberga najsilniejszy wpływ miały przekonania epoki beatu (nie zdołała nawet trwale zmienić tego późniejsza praktyka buddyzmu zen): „,Ginsberg wybrał inną drogę: od uniwersum do własnego Ja. Nigdy nie wyrzekł się swoich przekonań z epoki beatu, to właśnie one były warunkiem koniecznym do jego duchowych poszukiwań i przemian"29.

Krańcowy etap tych poszukiwań zdaje się przedstawiać kolejna („,uniwersalna”) strofa-zjej słów przebija zniecierpliwienie, widoczna jest eskalacja bezradności i niepewności:

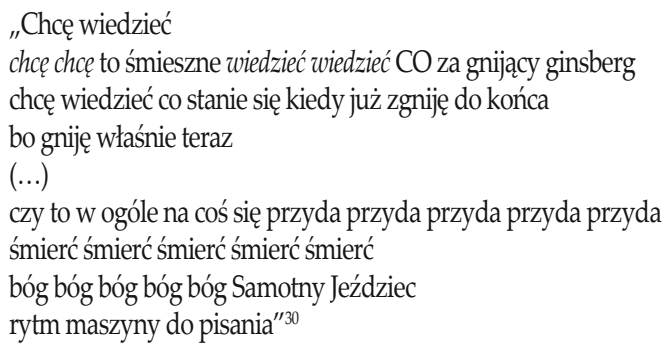

Z jednej strony całkowita redukcja siebie do poziomu ciała (skoro „gniję właśnie teraz", to - umieram), z drugiej dezorientacja i niezdecydowanie, czy tak naprawdę potrzebna jest wiedza wykraczająca poza elementarne ziemskie doświadczenie; czy istnieje w ogóle rzeczywistość poza nie wykraczająca. Frustrująca jest konkluzja: „mój tyłek włóczy się po wszechświecie za wiele wiem/ i nie dosyć", w świetle której zgromadzona przez „praktykowanie życia” wiedza jest zbyt obszerna, a mimo to nie pozwala dowiedzieć się najważniejszego. Nieprzypadkowo przy słowie „śmierć" pojawia się wyraz „bóg” - tą dosyć przewidywalną drogą skojarzeń dochodzi Ginsberg do głęboko zakorzenionego i schowanego przeświadczenia o silnym związku tych dwu zjawisk. W osądzeniu, czy związek ten oparty jest na relacji warunku, pomocna znów może być biograficzna opowieść H.Ch. Kirscha, w której znaleźć można takie słowa: „Po kolejnym zażyciu narkotyku [Ginsberg - przyp. autora] widzi połączone oblicze Boga i Śmierci. Bóg jest Śmiercią. Śmierć jest Bogiem. Allen prowadził długą rozmowę z tą zjawą. Pyta, jak powinien zachowywać się wobec kobiet - to jeden z jego zasadniczych problemów - i otrzymuje odpowiedź: »Kochaj je! «"31. Doświadczenie narkotyczne leży więc u podstawy rozpoznania utożsamiającego Boga ze Śmiercia, czego literackim odbiciem może być wspomniany fragment Meskaliny. Co ciekawe, słowa H.Ch. Kirscha rzucają też dodatkowe światło na wyznanie: „Tak, powinienem być porządny, powinienem się ożenić/ zrozumieć wreszcie o co w tym wszystkim chodzi/ ale nie mogę znieść tych kobiet wokół mnie". Kwestia stosunku do przedstawicielek przeciwnej płci nurtowała poetę i zajmowała go w znacznym stopniu; jej istota jest niewątpliwa również

28 Refleksja socjologiczna Zygmunta Baumana o depersonalizacji w nowoczesności jest tu przydatna, ponieważ zaskakująco dobrze oddaje istotę żalu za utraconą indywidualnościąi zmarginalizowaną intymnością: „Owa szczególna indywidualność jest anonimowa i pozbawiona twarzy, oskrobana do uniwersalnego kośćca, ogołocona ze wszystkiego, co idiomatyczne i charakterystyczne; z jakiejkolwiek cechy osobistej, która mogłaby stanąć na przeszkodzie jej całkowitej wymienialności. (...) Otoczenie składa się z innych jednostek o podobnych cechach, istot poddających się czysto ilościowej obróbce”. Zob. Z. Bauman, Socjalizm. Utopia w działaniu, Warszawa 2010, s. 42.

29 H. Kirsch, W drodze. Poeci pokolenia beatników, Warszawa 2006, s. 304

30 A. Ginsberg, Meskalina..., dz. cyt., s. 127-131.

31 H. Ch. Kirsch, dz. cyt., s. 296

OGRODY NAUK I SZTUK NR 2014 (4) 
w kontekście homotekstualnym. Wyznanie z Meskaliny jawi się tu jako odpowiedź na polecenie zjawy - hybrydycznej formy Boga i Śmierci!

Istotne spostrzeżenia pojawiają się we fragmencie kolejnym. Łącznikiem między nim a poprzednią strofą jest dwukrotnie wspomniana maszyna do pisania (symbolizująca wiersz powstający „na gorąco”), którą traktować należy jako przykład ginsbergowskiej poetyki asocjacji: częstotliwość wypowiedzeń wyrazów „bóg” i i,śmierć" przypomina mu stukanie w klawisze maszyny - i na tym mogłaby skończyć się jej obecność w utworze. Tu staje się jednak ona punktem wyjścia do „Maszyny” pisanej wielką litera; niby niewiążąco przywołanym obrazem, który otwiera pokłady dalszych skojarzeń. „Bębnienie w Maszynę” staje się określeniem życiowej aktywności Ginsberga, frazą-nośnikiem dużego ładunku wartościującego czynność i określającego sytuację poety. „JJak tym bębnieniem w Maszynę zasłużyć się Niebiosom” - pyta, a formułując swe pytanie w tekście uwydatnia ostatecznie pewną ciekawą różnicę: słowa „bóg" i „śmierć" pisane są małymi literami, w przeciwieństwie do „Maszyny"32 czy „Niebios". To znak dostosowywania świata do prywatnej hierarchii bytów, a właściwiej - absolutów, asekuracyjny głos w obronie nie konkretyzowania niepoznanych jeszcze Niebios jako „Boga", ponieważ ten nie jest namacalny ${ }^{33}$. „Niebiosa” odsyłają przede wszystkim do kategorii judeochrześcijańskich, co kłóciłoby się z dotychczasową wyobrażeniem płaszczyzny duchowej Meskaliny, może jednak poeta wolał po prostu unikać od wołań do konkretnych istot i pozostać przy realiach „topograficznych"? Niejasne są motywacje Ginsberga, który w wierszu LSD czyni takie z kolei wyznanie: „,ja który nienawidzę Boga i nadaję mu imię/ ja który robię błędy na wiekuistej maszynie do pisania" ${ }^{\prime \prime 4}$.Z potrzeby desygnowania bytów i przypisywania im określonych ról w swoim mikrokosmosie, rodzą się wewnętrzne konflikty. Namacalna jest z pewnością Maszyna, która stanowi dla poety kategorię absolutną.

Kwestia uniwersalizacji i indywidualizacji pojęć we własnym językowym tworzywie literackim stanowi dobry pretekst, by wspomnieć o niezwykle istotnym źródle inspiracji Ginsberga, jakim jest postać i twórczość Walta Whitmana. Artur Międzyrzecki określa całą następującą po nim poezję amerykańską jako „cykl zerwań i nawiązań do W. Whitmana” ${ }^{\prime \prime 35}$. Jeśli zestawić ze sobą oś historycznoliteracką rozwoju tej poezji z osią naprzemiennych zerwań i nawiązań do twórcy, to punkt na prostej, którym oznaczona będzie działalność literacka Ginsberga, całkowicie znajdzie się w strefie wpływów dziewiętnastowiecznego poety. Wspomniane zagadnienie uniwersalizacji-indywidualizacji można prześledzić na przykładzie wielu utworów W. Whitmana. Manifestacyjny wiersz Opiewwam własne Ja dostarcza najdokładniejszej chyba wykładni takiej poetyckiej metody: wielką literą zapisywane jest nie tylko „Ja”, lecz także „Męskość”, , „Kobiecość”, ,Demokracja”.... 36 . Autor Skowytu zapożyczając chwyty poetyckie od W. Whitmana nie staje się odosobnionym przypadkiem, jestjednak przykładem dość osobliwym. Szczególnie serdeczny stosunek do ojca współczesnej poezji amerykańskiej uwidacznia się w licznych wierszach, w których Allen Ginsberg bezpośrednio powołuje się na swojego mistrza (jak choćby zwroty do Whitmana w Supermarkecie w Kalifornii, czy utwór Ja tak kocham starego Whitmana). Można jednakże pokusić się o anachronizm i odnaleźć też w wielu tekstach Whitmana sygnały, lub całe myśli, które Ginsberg podejmuje w Meskalinie - choćby z Lusterka:

„Trzymaj je mocno - spójrz, kogo odbija (kto to? czy ty?),

Poza schludnym kostiumem plugastwo tylko i proch,

Przepadł już oka błysk, głos dźwięczny, krok sprężysty,

Teraz to niewolnika oko, głos, ramiona, krok, (...) syfilityka ciało,

płuca gnijące po kawałku, żołądek skisły i toczony rakiem ${ }^{\prime \prime 37}$

Pewne zbieżności dostrzec można także w biografiach twórców: W. Whitman przejąwszy się w latach wojny domowej losem rannych żołnierzy, został ochotniczym sanitariuszem armii Północy, Allen Ginsberg zaś, jak przypomina H.Ch. Kirsch: „rozpoczynając studia, przyrzekł sobie pomagać wszystkim cierpiącym. Chciał wtedy specjalizować się w prawie $\operatorname{pracy}^{\prime \prime 38}$.

32 W thumaczeniu B. Barana - „Klawiszy”, w oryginale - ,Typewriter”.

33 Bardzo istotny w tym kontekście staje sie fragment Kadyszu, w którym Ginsberg stara sie dookreślić Boga. Pisze: „Bezimienny, Z jednym obliczem, Na zawsze poza mna, bez początku, bez końca, Ojcze w umieraniu. (...) chciałbym wielbić Ciebie, Niebiosa, po Śmierci, tylko Jedynego w Nicości, nie światło lub ciemność, Wieczność Bezdzienną". Zob. A. Ginsberg, Kadysz, [w:] Tenże, Kadysz..., dz. cyt., s. 57.

34 A. Ginsberg, LSD, [w:] Tenże, Utwory poetyckie, Kraków 1984, s. 97-103.

35 A. Międzyrzecki, Od autorów antologii, [w:] J. Hartwig, Tenże (oprac.), ...opiewam nowoczesnego czlowieka..., dz. cyt., s. 9.

36 W. Whitman, Opiewam własne ja, [w:] J. Hartwig, A. Międzyrzecki (oprac.), ...opiewam nowoczesnego człowieka ..., dz. cyt., s. 4-5.

37 Tenże, Lusterko, J. Żuławski (tłum.), [w:] J. Hartwig, A. Międzyrzecki (oprac.), dz. cyt., s. 15.

38 H. Ch. Kirsch, dz. cyt., s. 295. 
Dalszy ciąg utworu również przynosi kilka innych reminiscencji:

„Nudziarz ze mnie zmieniam płytę Gregory och! świetny on robi to o co mi chodzi zbyt świadom jestem miliona uszu" ${ }^{\prime \prime 39}$

Gregory jest najprawdopodobniej wspomnianym już Gregorym Corso. „Miliony uszu” kojarzą się zaś z „,wielorakim milionookim potworem" $\mathrm{z}$ wiersza LSD (Kwas lizergowy) $)^{40}$. Dopełnieniem antropocentrycznego portretu miliona uszu jest tutaj tyleż samo oczu, jednak to nie wszystko - wiersz Psalm magiczny pozwala ukończyć wizerunek hiperbolicznego indywiduum tak silnie zaznaczającego się w poezji Ginsberga, uzupełniając go o milion ust: „,niechaj mój głos bardziej brzydotą zarechocze niż rzeczywistościa, pomidorem myśli głoszącym Ciebie milionami ust" ${ }^{\prime \prime 1}$.

Ten fragment Meskaliny kończy się dosyć bezkompromisowo, wręcz urywa: „Teraz przerywam wiersz by kontemplować drak". Uderzające jest hebrajskie znaczenie tego wyrazu " gówno" ${ }^{\prime \prime 2}$. Zestawienie języka, w którym napisany został Stary Testament z jego aktualnym w utworze zastosowaniem budzi zrozumiałą konfuzję. Czy pomysł na tak dosadne i barbarzyńskie pomieszanie tonów poetyckiej ekspresji to tylko przejaw zapędów obrazoburczych? Nie obce były poecie takie skłonności - dowodem jest choćby słynny Przypis do „Skowoytu” z zestawieniami wyrażeń burzacymi wszelkie standardy decorum. W pamięć zapada także ginsbergowa interpretacja IV prawdy Bodhisattwy: „Zamienianie gówna $\mathrm{w}$ róż $\mathrm{e}^{\prime \prime 43}$. Takie złamanie dykcji tłumaczyć można jednak inaczej. Trzeba wziąć po uwagę fakt, że Meskalina pochodzi ze zbioru Kadysz i inne wiersze, a więc wyboru wierszy penetrujących judaistyczne korzenie Ginsberga, tekstów, w których można odnaleźć silne wpływy poezji Charlesa Reznikoffa. Zaadaptowanie tradycji hebrajskiej na potrzeby poetyckiego wyrazu owocować mogło pragnieniem dostosowania do niej wszystkich sfer życia i to właśnie w taki sposób - nie poprzez ich nobilitację (w pewnym sensie będącą wówczas równoznaczną z sakralizacją), ale poprzez uniwersalizację jezzyka hebrajskiego. Wszystko, co doświadczalne, musi się także urzeczywistnić w języku, aby ten nie był tworem oderwanym od rzeczywistości. Nie nowe jest takie mieszanie tonacji - w Kadyszu padają słowa: „Aj! aj! coraz z nami gorzej! Tkwimy w gównie! A ty odeszłaś, Śmierć zezwoliła, Śmierć okazała łaskę, skończyłaś z epoka, Bogiem"44. Warto jeszcze przytoczyć sąd Grzegorza Musiała, sugerującego dwa powody zwrotu pierwszego powojennego pokolenia amerykańskiego do Starego Testamentu: „zjudaizowanie się" amerykańskiej kultury oraz nieufność do Europy rzymskiej i katolickiej, która wydała na świat potworne dziecko wojny ${ }^{45}$. Motywacji Ginsberga nie sposób odgadnać, i też nie najistotniejsza jest ona w obliczu refleksji kulminacyjnej i najbardziej dosłownej:

„rozum to kupa śmieciat

świat to kupa śmiecia

człowiek w połowie śmieć

a samo śmiecie $\mathrm{w}$ grobie ${ }^{\prime \prime 4}$

Człowiek musi więc umrzeć, aby dopełnić tego, co jest już w nim zaczęte: gnicie. Skoro jest w połowie śmieciem, musi stać się nim w całości. Śmierć to niezbędny warunek kompletności istoty ludzkiej, zdaje się mówić gnijący Ginsberg. To już przedsionek wniosku ostatecznego, to moment, w którym stwierdzenie swojej zupełnej bezwartościowości odbija się

39 W oryginale: „I'm stuck change the record Gregory ah excellent he’s doing just that (...)”. Polskie przekłady, zarówno cytowane powyżej thumaczenie G. Musiała, jak to dokonane przez B. Barana (,Zmieniam płytę Gregory ach doskonały on robi co należy”) wydają się nie wykorzystywać potencjału frazy. Wyraz „stuck” oznacza przede wszystkim ,unieruchomiony”, a to rzuca nowe światło na dalszy tok wypowiedzi: może być to prośba do Gregorego, by ten zmienił płytę. B. Baran zupehnie pominął wyrażenie „I’m stuck”, G. Musiał przełożył je dość nieprzekonująco w tym kontekście (,nudziarz ze mnie”). A. Ginsberg, Meskalina..., dz. cyt., s. 127-131.

40 A. Ginsberg, LSD, [w:] Tenże, Utwory poetyckie..., dz. cyt., s. 97-103.

41 A. Ginsberg, Psalm magiczny, [w:] Tenże, Kadysz..., dz. cyt., s. 141. Taką wędrówkę można poprowadzić jeszcze dalej, np. w wierszu Wrzesień na Jessore Road następuje dalsza multiplikacja, tym razem - miliony ojców, matek, braci, dziewcząt, dusz...

42 Stąd - thumaczenie B. Barana: „Odchodzę z wiersza ku kontemplacji gównianej”.

43 H. Ch. Kirsch, dz. cyt., s. 293

44 A. Ginsberg, Kadysz, [w:] Tenże, Utwory poetyckie..., dz. cyt., s. 53.

45 G. Musiał, Żelazne regimenty mody, [w:] A. Ginsberg, Kadysz ..., dz. cyt., s. 157.

46 W thumaczeniu B. Barana - „tandeta umysłu” - uwagę zwraca mniejszy ladunek emocjonalny.

47 „Trash of the mind/ trash of the world/ man is half trash/ all trash in the grave” - B. Baran proponuje thumaczenie: ,....) cała tandeta w grobie”, ja zaś proponuję formę: , „...) a całość śmiecia w grobie”, ponieważ wydaje się być najwierniejszą - jeśli nie słowom, to przynajmniej idei Ginsberga; A. Ginsberg, Meskalina..., dz. cyt., s. 127-131.

Ogrody NAUK I SZTUK NR 2014 (4) 
i zaczyna funkcjonować samodzielnie, obleczone w szaty nowego, finałowego odkrycia: to nowe narodziny są etapem kluczowym, nie sama śmierć; śmierć pełni funkcję służebną w stosunku do jej następstw i konsekwencji. Zrezygnowany, nie pozwala sobie jednak upajać się tym wnioskiem, dosyć szybko zmieniając jego wydźwięk na pesymistyczny:

\author{
„czy gotów jesteś urodzić się od nowa \\ aby uwolnić się od tego świata aby wstąić w niebiosa \\ lub się uwolnić lub się uwolnić \\ i zamknąć wszystko - i ujrzeć życie - wieczność całą - odeszłe \\ i obrócone w marność (...) \\ Nie ma Chwały dla człowieka! Nie ma Chwały dla człowieka! \\ Nie ma chwały dla mnie! Nie ma mnie!"48
}

Wyraźne nawiązanie do buddyjskiej nauki o karmie i odrodzeniu wpisuje pragnienia cierpiącego w rejestr odwiecznych tęsknot za istnieniem wyjętym spod praw spiralnego modelu ewolucji. Buddyzm podaje zresztą niezwykle interesującą odpowiedź na pytanie o genezę ginsbergowskiej „obsesji śmierci”. W jednym z wykładów Sanharakszity znaleźć można taką interpretację: „,(Trzecia) trucizna to pragnienie (intensywne, neurotyczne pożądanie): żądza posiadania tego, tamtego i jeszcze czegoś innego. Jest to pierwotne, podstawowe skalanie, bardzo trudne do przezwyciężenia. Być może ze względu na władzę, jaką ma ono nad nami, jako antidotum zaleca się nie jedna, ale trzy metody medytacji”" ${ }^{\prime 29}$. Jeśli więc, w świetle rozważań nad słowami Judith Butler, jawi się gnijacy Ginsberg jako dręczony silnym poczuciem straty i pragnieniem, wówczas jego stan emocjonalny („,kontemplację śmierci”) można wytłumaczyć jako metodę przezwyciężania ",trucizny pragnienia”: „Druga metoda przezwyciężania pragnienia (...) to kontemplacja śmierci, która musi opierać się na silnym fundamencie uwagi i pozytywnych emocji" ${ }^{\prime 50}$. W tym przypadku jednak zachwiany został istotny komponent równowagi i spokoju trudno mówić o kontemplacji, uruchomiony został cały zasób radykalniejszych środków autoanalizy.

Nie można pominąć ważnego tropu, jakim jest zwrot do Wiliama Carlosa Williamsa. Ginsberg zastanawia się „, $\mathrm{O}$ czym rozmyśla Williams w Paterson" i pyta go wprost: „Williamsie, czym jest śmierć?”. Adresat pytania, mistrz poety (a także autor przedmowy do Skowytu), nie bez powodu wzmiankowany tutaj jest w kontekście swojego poematu Paterson; to w nim zamieszczonych jest kilka listów Ginsberga. Próbę odpowiedzi na pytanie można jednak znaleźć już w wierszu Williamsa Śmierć, który przedstawia zgon w kategoriach semantycznych wstydu, hańby, nikczemności i politowania. Czy to nie williamsowską metodę uprawiania introspekcji poprzez poezję wziął sobie do serca mentor bitników? Postulat odkrywania uniwersum przez szczegót, układania rzeczy, a nie idei, tak kategorycznie wyrażony w wierszu W rodzaju piosenki znajduje swe echo także w Patersonie „,Słuchaj, nie ma innych pojęć niż zawarte w rzeczy” - mówi W. C. Williams. Skoro jednak rzecz, jak wszystko, staje się śmieciem - wówczas trzeba sięgać do idei, te zaś są niedostępne! - zdaje się dopowiadać Ginsberg. Puenta może być więc tylko gorzka:

„Nie ma sensu pisać gdy duch nie prowadzi" ${ }^{11}$

\title{
KONSTRUKCJA PODMIOTU I FRAZY [D.A. PoWelL]
}

Od przepełnionej rezygnacją konkluzji Ginsberga pozornie bardzo dużo dzieli pytanie-szlagwort: „,kkarbie czy mnie udusisz: poduszką w myszki mickey", rozpoczynające i dające tytuł wierszowi D. A. Powella, pochodzącemu z wydanego w roku 2000 tomiku Lunch. Utwór gromadzi w sobie wszystkie cechy poetyki Powella, niezwykle idiomatycznego autora, który już pierwszym tomikiem (Tea z 1998 r.) stworzył łatwo rozpoznawalny styl, utrwalony trzema kolejnymi zbiorami liryków. Oprócz niepowtarzalnej (i niezmiennie stosowanej) budowy graficznej, wiersze tego autora charakteryzują się subtelnością i lekkościa, która zazwyczaj połączona zostaje z przejmującą i bezpretensjonalnie ostrą treścią. Nie inaczej jest tutaj: podmiot liryczny zadaje swoje pytanie:

48 Tamże.

49 Sangharakszita, ,Śmierć” Buddy, [w:] Tenże, Kim jest Budda?, Kraków 2004, s. 153.

50 Tamże.

51 W oryginale: „No point writing when the spirit doth not lead” (doth to archaiczna forma trzeciej osoby czasownika “do" - obecne "does”; operator). To istotny trop - kolejne skojarzenie zjęzykiem biblijnym (w języku polskim wers mógłby brzmieć „Nie ma sensu pisać, kiedyż duch nie prowadzi”, gdyby pominąć fakt stosowania formy „kiedyż” w sformułowaniach pytających). B. Baran zmienia nieco wydźwięk wersu, dodając na końcu słowo: „pióra”. A. Ginsberg, Meskalina..., dz. cyt., s. 127-131. 


\begin{abstract}
„skarbie czy mnie udusisz ${ }^{22}$ : poduszką w myszki mickey
kiedy już zmizernieję. $\quad$ i czy twoje zastrzyki ${ }^{53}$

skutecznie mnie uśpią: kiedy niemal nie będzie mnie w ogóle

będę strzępem krztą okruchem byle drobiną ${ }^{54} \quad$ spętaną bólem." ${ }^{\prime 55}$
\end{abstract}

Już pierwszy czterowers egzemplifikuje wszystkie te cechy powellowskiej poezji: czułostkowy ton (którego przejawem jest absurdalna "poduszka w myszki mickey”, zwrot „skarbie”) kontrastuje z dosadnością i sugestywnością dalszego opisu. Podobnie jak Meskalina, utwór podejmuje problem somaestetyczneje świadomości człowieka. Tu poczynić trzeba uwagę, która znacząco wpłynie na rozumienie licznych wątków twórczości Amerykanina: należy ona do tej gałęzi poezji gejowskiej, której specyfiką jest naznaczenie stygmatem AIDS. Fakt autobiograficzny jakim dla poety było zachorowanie, nie pozostaje bez wpływu na kreowaną przez niego rzeczywistość literacką. Osobliwy filtr poetycki, przez który przechodzą jego wiersze, zazwyczaj nie przepuszcza wyrazu „AIDS” do tekstu utworu, budując charakterystyczny styl niedopowiedzeń i metafor. Dzieje się tak choćby w omawianym liryku, w którym nazwa choroby nie jest wzmiankowana, jednak jego osadzenie w znamiennym kontekście pozwala mieć pewność co do takiego rozpoznania - lecz i w wielu innych wierszach, które dużo dosłowniej sugerują i podejmują kwestię AIDS (np. w [listen mother, he punched the air: I am not your son dying] ze zbioru Cocktails). Powell opowiada o śmierci w sposób przejmujący, ale przewrotny i zaskakujący, wprawiający często w zdumienie. Jest w jego poezji dosłowność i cierpienie, jednak nie wywołują one chaosu i literackiej brutalności znanej z przedstawień Ginsberga. Tu siła rażenia zawiera się w uśpionej mocy, w pozornym spokoju iniewiarygodnym opanowaniu słowa oraz - powściagliwości. Jakby w odpowiedzi na (zadane w eseju O chorowaniu) retoryczne pytanie Virginii Woolf o to, dlaczego choroba nie zajęła wśród uniwersalnych tematów literackich równie poczesnego miejsca co miłość, Powell pokazuje, że zawładnęła równie totalnie ludzkim doświadczeniem, lecz dokonała tego w sposób dużo mniej widowiskowy i oczywisty.

Powściagliwość wiersza [skarbie czy mnie udusisz: poduszka w myszki mickey] widoczna jest doskonale w sposobie konstruowania podmiotu. W miejsce ginsbergowskiego ekshibicjonizmu (rodem z Autobiografii Lawrence'a Ferlinghettiego) ${ }^{57}$ i skłonności do werbalizacji każdej myśli, Powell proponuje model ukrytego , ,ja” lirycznego, które nie definiuje się permanentnie i w sposób tak nieposkromiony, lecz mówi o sobie tyle, ile określają wymagania wypowiedzi. Czytelnik nie dowiaduje się, z czego składa się teraźniejsza rzeczywistość podmiotu, poznaje za to jego obawy i pragnienia. To ciekawy zabieg, bo przecież przez tę antycypacyjną formę ekspresji odsłania się też całkiem istotna część tego, co obecne i dla osoby mówiącej konstytutywne. „Niedopowiedziany" charakter wypowiedzi dostarcza kilku możliwości odczytania całej sytuacji: niejasne jest, czy pytania te w rzeczywistości są wypowiadane i kierowane do adresata ${ }^{58}$, czy pozostajaj jedynie w sferze przypuszczeń. W zależności wybranej ścieżki interpretacyjnej, utwór staje się albo monologiem wewnętrznym, albo prośbą skierowaną do ukochanego. Dodatkowego problemu dostarcza kwestia polskiego przekładu; fraza „darling can you..." może oznaczać zarówno pytanie, jak grzecznościową formę polecenia.

Trudność potęguje fakt, że Powell nie używa w tekście pytajników. Stosuje charakterystyczne dla siebie dwukropki oraz kropki jako jedyne znaki interpunkcyjne, co ma istotny wpływ na charakter jego utworów. Ich rytm należałoby nazwać wersetowym, płynnym; oryginalna konstrukcja, która cechuje każdy wiersz poety, szybko stała się jego znakiem rozpoznawczym, wpływając na atrakcyjność liryków. Wersy są długie (w tomikach niektóre z wierszy drukuje się po-

52 Przethumaczenie frazy „,darling can you kill me...” jako „czy mnie udusisz” jest zrozumiałą decyzją M. Tabaczyńskiego (,zabić poduszką” znaczy przecież „udusić”), gdyby jednak wymagać wiernego przekładu, wówczas brzmieć powinna ona „skarbie czy mnie zabijesz: poduszką w myszki mickey”, co mogłoby jej dodać większej dozy dramatyzmu.

53 Fragment ten jest przykładem złagodzenia wymowy oryginalnego utworu, na które często decyduje się thumacz. „Exhaust and hose” oznaczają w przybliżeniu - rurę wydechową i wąż, zaś zwrot „put me out”, przethumaczony jako „,skutecznie mnie uśpić”, to dosłownie „wyeliminować z gry”, ale i ,ugasić" - stąd nie jest zaskakujące pojawienie się, ,węża”, „Zastrzyki”, wydają się jednak bardziej odpowiednimi, ze względu na trudność w przetłumaczeniu enigmatycznego zwrotu z, ,wężem” i „wydmuchem” (dosł. „exhaust”) i, przede wszystkim, ze względu na założenie rymowości wiersza.

54 W oryginale: ,a tatter a snip a silver a whit a tittle"-rytmiczna enumeracja, której rytm uwypuklany jest także wewnętrznym rymem.

55 D. A. Powell, [skarbie czy mnie udusisz.... dz. cyt., s. 147.

56 Definicja Richarda Shustermana: „Somaestetykę można prowizorycznie zdefiniować jako krytyczne, melioracyjne badanie doświadczenia człowieka i użycia ciała jako ośrodka sensoryczno-estetycznej świadomości [aisthesis] oraz kreatywnego kształtowania siebie”. Zob. R. Shusterman, Świadomość ciała. Dociekania z zakresu somaestetyki, Kraków 2010, s. 40.

57 Nazwisko L. Ferlinghettiego wspomniane zostało nie bez powodu - Ginsberg z pewnością inspirował się autobiograficznym charakterem jego utworów, zwłaszcza Autobiografii; pisarz był właścicielem wydawnictwa City Light Books, które wydało Skowyt i inne wiersze oraz brało udział w batalii sądowej o prawo do jego druku.

58 Adresatem jest tutaj poeta Sam Witt, któremu dedykowany jest utwór.

OGRODY NAUK I SZTUK NR 2014 (4) 
ziomo) i ograniczone myśla, zwrotem, fraza, którą mają wyrażać; mają charakter "mówiony". Dwukropki stanowią sygnał i zapowiedź dopełnienia pierwszego członu myśli, częścią zawierająca jej rozwinięcie, lub konkretyzację, kropki zaś informują najczęściej o rozpoczęciu nowej refleksji. Można by stwierdzić, że sposób poetyckiego obrazowania Powella przebiega wzdłuż osi „,sygnał-rozwinięcie”, , „kompleks-konkretyzacja” lub, w częstych przypadkach, „problem-rozwiązanie". Sam twórca przyznaje w krótkim quasi-wywiadzie zamieszczonym w antologii ${ }^{59}$ współczesnej amerykańskiej poezji gejowskiej: „Zdaje się, że na początku myślałem po prostu w kategoriach frazy, a dopiero później zacząłem szukać naczynia, które by ją pomieściło".

\section{Choroba duszy I CIAŁA}

Kwestią równie nieodgadnioną jak dwuznaczność formuły „can you...” jest to, czy podmiot wiersza rzeczywiście choruje i przewiduje (nieunikniony w końcu) stan stopniowego pogarszania się swojego zdrowia, czy może jest to osoba całkiem zdrowa, która zastanawia się tylko nad prawdopodobieństwem otrzymania pomocy od bliskiego jej człowieka w projektowanej sytuacji. Może być tak, że przygotowuje się na ewentualne nadejście najgorszego, będąc świadomą szalejącej epidemii. Jeśli przyjąć, że wypowiadającym słowa jest sam D. A. Powell, wówczas wiersz wpisywałby się w dosyć silnie zaznaczający się nurt poezji strachu spowodowanego AIDS, które zbiera żniwa także w świecie poetów (przypadki umierających twórców - np. Tima Dlugosa lub ich przyjaciół - np. kochanka jednego z ważniejszych amerykańskich poetów współczesnych, Marka Doty'ego) ${ }^{60}$. Michał Tabaczyński pisze wręcz w swojej antologii, że doświadczenie AIDS zbliżyło poezję tę do uniwersalnej kondycji ludzkiej. Wiersz Powella czytać można bez homoseksualnego kontekstu, nie traci wówczas w żadnym stopniu swojego dramatycznego wydźwięku.

$$
\begin{array}{ll}
\text { "czy trzepniesz w potylicę: } & \text { ciosem na odlew } \\
\text { tę resztkę mnie robiącą pod siebie. } & \text { śliniącego się jak niemowlę }{ }^{\prime \prime 2}
\end{array}
$$

Od tego fragmentu wiersz podąża w stronę dosłownej fizjologicznej i anatomicznej charakterystyki chorego. Wymyślne metafory śmierci, takie jak: „'zy dokręcisz kurek/ wyciągniesz wtyczkę z gniazdka” towarzyszą całkowicie odmetaforyzowanym opisom. Unoszące się nad całością tekstu wrażenie wywołane przez tytułową „poduszkę w myszki mickey” czyni ją coraz bardziej absurdalna, okazując ją niemal jako przejaw czarnego humoru ${ }^{63}$; jest to nieprawdopodobnie mocne poetycko zestawienie potęgujące efekt zaskoczenia, doskonale opanowany przez Powella. Uśmiech, który może wywołać lektura pierwszego wersu wiersza, ustępuje ostatecznie przy frazach typu „resztka mnie robiąca pod siebie”.

Stosunek podmiotu do śmierci określany jest jego stosunkiem do ciała - to dobry probierz zainteresowania kwestiami ostatecznymi. Sporo cech zbliża go do sytuacji gnijaccego Ginsberga - podobnie jak on, powellowski bohater wyznaje (co znamienne - nie ważne czy świadomie, czy nieświadomie) swoistą formę kultu ciała, objawiającą się choćby samym zajmującym go zagadnieniem. To właśnie ciało jest przyczynkiem do refleksji. Gdy przestaje spełniać swoje funkcje oraz ulega degradacji estetycznej (z kategorii piękna do kategorii brzydoty), wywołuje zaniepokojenie i natychmiastową myśl o śmierci. Rola, którą odgrywa tu soma, jest istotna i zdaje się konstytuować w oparciu o całkowitą negację podejścia platońskiego przedstawionego w Fedonie, dialogu greckiego filozofa. Owa koncepcja ciała jako całkowicie szkodliwego, zniekształcającego obraz świata i utrudniającego poszukiwanie wiedzy, stanowi zaprzeczenie jego istoty w percepcji podmiotów lirycznych obu wierszy, a także ogólnie w spojrzeniu homoestetycznym. To zdecydowanie bliższe jest filozofii Michela Foucaulta, która broni ciała pojmowanego jako istotne miejsce samowiedzy i twierdzi, że „autokreacja jest nie tylko sprawą zewnętrznej stylizacji siebie za pomocą wyglądu własnego ciała, lecz transfiguracją wewnętrznego poczucia własnego ja" ${ }^{\prime \prime 4}$. Sytuację komplikują jednak często różne okoliczności, w obliczu których negacja owego ja wydaje się być rozwiązaniem nieuniknionym. Strategię tego odrzucenia tak analizuje Maurice Merleau-Ponty: „Wszechogarniające doświadczenie cielesnej niemocy może być filozoficznie najpoważniejszym powodem, aby ciało odrzucić i zrezygnować z poglądu, że ciało definiuje ludzką tożsamość. Somatyczna bezsilność, tak dominująca w chwili śmierci, jest obecna rów-

59 D. A. Powell, Moim Wergiliuszem było wyzwanie, [w:] M. Tabaczyński (red.), Parada równości..., dz. cyt., s. 203-204.

60 Kenny Fries poświęcił mu jeden ze swoich wierszy - Do poety, którego kochanek zmart na AIDS.

61 D. A. Powell, Moim Wergiliuszem..., dz. cyt., s. 203-204.

62 D. A. Powell, [skarbie czy mnie udusisz..., dz. cyt., s. 147.

63 Pytanie o uduszenie poduszką w kontekście dalszej treści wiersza zaczyna przypominać pragnienie bycia zapamiętanym jako osoba młoda, tu: zdrowa i atrakcyjna. Podobne pytanie zadaje Rafael Campo w wierszu Coś na temat prawa do małżeństwa: „Będziesz mnie pamiętał takiego, jakim jestem dzisiaj?”

64 R. Shusterman, dz. cyt., s. 29. 
nież na co dzień - w chorobie, kalectwie, zranieniu, bólu, zmęczeniu oraz w niemocy, którą przynosi starośs' ${ }^{\prime \prime 65}$. W takiej sytuacji daje się poznać powellowski podmiot liryczny ${ }^{66}$.

Choroba to sytuacja szczególna, która zdaje się katalizować pojawienie się wątpliwości metafizycznych -nie dzieje się tak jednak w wierszu Powella, zaskakująco dokładnie wypranym z kategorii transcendencji, tak (być może pozornie) bliskich bohaterowi Meskaliny. Podmiot nie zastanawia się, co czeka go po śmierci, chce tylko jak najszybciej jej doświadczyć, gdy życie zacznie mu dostarczać zbyt wiele bólu i cierpienia. Kiedy ciało stanie się bezużyteczne i kłopotliwe, człowiek mimowolnie również stanie się takim. To proste wnioskowanie przemawia za utożsamieniem człowieka z ciałem, nasuwa znów skojarzenia z mięsnościąi reifikacją. Portret podmiotu jest pełen sprzeczności: jawi sięjako osoba cynicznie chłodna, ponieważ z chirurgiczną precyzją analizuje wszystkie możliwe stany swojego cierpienia oraz używając wyszukanych metafor prosi o jego skrócenie - $z$ drugiej strony, wypowiada się jako jednostka niezwykle wrażliwa i bojąca się własnej przyszłości. Za taką interpretacją przemawia cały utwór, nie zaś poszczególne jego wersy; pobudki, zjakich chory artykułuje swoje prośby, są bardzo ludzkie. Zadziwia przy okazji szczegółowa znajomość procesów, które dotykają ofiary AIDS oraz konkretność pytań/próśb - zupełnie jakby wszystko było już przewidziane a dalsze następstwa wydarzeń stanowily jedynie stopniową realizacją przyjętego scenariusza.
"charczącego pod namiotem tlenowym. ${ }^{67}$
wyciągniesz wtyczkę z gniazdka:
czy dokręcisz kurek
kiedy już stracę czucie w nogach.
czy targniesz zaciskającym się sznurem
kiedy mój uścisk się rozluźni" ${ }^{\prime 6}$

W tym fragmencie wyraźnie zaznaczają się cechy unikalnej poetyki zaskoczenia: kwestie śmiertelnie smutne i poważne przemycane są $\mathrm{w}$ wyrażeniach niewinnych; przecież w pytaniu o wyciagnięcie wtyczki z gniazdka, czy dokręcenie kurka, zawarta jest prośba o śmierć, wypowiedziana z taką lekkościa, jakby była prośbą o podanie szklanki herbaty. Jedną z najdosadniejszych próśb o „podanie śmierci” jest pytanie o heroinę („,with your smack connections could you dose me. as I start my decline $\left.{ }^{\prime \prime}\right)^{69}$, które zostało zupełnie pominięte w przekładzie M. Tabaczyńskiego. W kontekście tej interpretacji porównawczej to jednak znaczący element próśb, ponieważ heroina przestaje być nieoczywistym sygnałem, stając się odpowiedzią na tytułową meskalinę z wiersza Allena Ginsberga $a^{70}$ Zestawienie tych środków ma wymiar symboliczny - każdy z nich pełni tak różne od siebie funkcje, jak różne są potrzeby obu mężczyzn, których portrety nakreślone zostały $\mathrm{w}$ wierszach. Potrzeba heroiny i potrzeba meskaliny (choćnie wyartykułowana, jednak przypuszczalnie będąca pretekstem do jej zażycia - i przez to bodźcem do zgłębienia siebie) zaczyna się jawić jako figura potrzeby ucieczki: ginsbergowskiej wewnętrznej podróży „„do" (psychicznej introspekcji) oraz-powellowskiej potrzeby ucieczki „od” (psychicznej i fizycznej).

„kiedy już stracę czucie w nogach. zostanie ze mnie marna trzcina wrak ruina ${ }^{71}$ gryp tryprów wysięków mnie wyrwiesz. w ostatniej godzinie.

\section{kiedy mój uścisk się rozluźni}

czy z tej próżni

czy mnie twoja kula ukoi

aniele: nie ma już światła które byłoby moim"72

65 Tamże, s. 80.

66 Poezja gejowska jest dobrą ,antyilustracją” popularnego poglądu (który rozwijała i z którym polemizowała m. in. Judith Butler) głoszącego, że w kulturze umysł jest kojarzony z męskością, zaś ciało z kobiecością. Richard Shusterman: „Jeśli mężczyźni są tradycyjnie postrzegani jako noszący znamiona podmiotowości i transcendencji/takie jak intelekt, wola, działanie/, to kobieta (...) jest zazwyczaj postrzegana wprost przeciwnie - jako przedmiot. Jest ona z istoty postrzegana jako swe ciało". Zob. R. Shusterman, dz. cyt., s. 121.

Ciekawa właściwość nieheteronormatywnego i homotekstualnego wymiaru wierszy przejawia się tym, że powellowski (a także ginsbergowski) podmiot liryczny przejawia troski właściwe (z punktu widzenia „kultury”) kobietom, nie tracąc jednak typowo „męskich” atrybutów wymienionych przez R. Shustermana.

67 Stowa „charczącego pod namiotem tlenowym” odnoszą się do poprzedniego wersu - stanowią dopehnienie charakterystyki ,śliniącego się jak niemowlę". W polskim przekładzie nie jest to widoczne, ponieważ te dwa opisy zostały oddzielone od siebie kropką. W oryginale pojawia się spójnik „or”- „lub”.

68 M. Tabaczyński przy każdym pytaniu stosuje partykułę,,czy”, po której bezpośrednio wprowadza istotę danej prośby, zás wiersz w swoim oryginalnym brzmieniu jest pod tym względem bardziej zróżnicowany. Powell używa form: „can you”, ,could you”, ,would you”, a w obrębie tej strofy: “won’t you” i “mightn’t you"; D.A. Powell, [skarbie czy mnie udusisz..., dz. cyt., s. 147.

69 Smack-slangowe określenie heroiny. Jest to pochodna morfiny -środka uśmierzającego ból; określenie żargonowe zostało więc niejako przeniesione w rejestr medyczny.

70 Meskalina - środek halucynogenny, posiadający właściwości psychoaktywne. Jego działanie określane jest niekiedy jako „rozświetlające umys"”.

71 W oryginale: , ,and I'm a thread a reed a wrack a ruin: of clap and flux and grippe”- druga enumeracja (po następującej w czwartym wersie i omówionej w przypisie 48), tym razem nie rymująca się w anglojęzycznym tekście, zaś wzbogacona o rym w polskim przekładzie.

72 D. A. Powell, [skarbie czy mnie udusisz..., dz. cyt., s. 147.

OGRODY NAUK I SZTUK NR 2014 (4) 
M. Tabaczyński dokonał również znacznej ingerencji w tekst wiersza - pozbawiając go całkowicie wersu o heroinie, naruszył jego konstrukcję i zmienił porządek łączności pytań-próśb z ich rozwinięciami. Pascalowsko brzmiące „Marna trzcina wrak ruina" połączone z "grypami tryprami wysiękami" stanowily integralny i samodzielny wers, zwrotu „czy z tej próżni (...) mnie wyrwiesz" nie było zaś wcale. Polski przekład stanowi nieco bardziej upoetyzowaną wersję wypowiedzi. Najbardziej widoczne staje się to przy prośbie ostatniej: „czy mnie twoja kula ukoi/ w ostatniej godzinie” to bardzo liryczna realizacja oryginalnego pytania: „would you put a bullet through me”. Niewątpliwą zasługą tumaczenia M. Tabaczyńskiego jest zachowanie oryginalnej i rozpoznawalnej formy wierszy D. A. Powella oraz, przede wszystkim, rymowanej postaci utworu. To niezwykle ważny komponent, ponieważ decyduje o melodyjnym, wręcz śpiewnym charakterze i tak już zrytmizowanego tekstu. Właściwość ta ma funkcję semantyczna, ponieważ wpisuje się w założenie lekkości i niepozorności tekstu podejmującego kwestie nielekkie.

Interesujące jest stopniowanie skali cierpienia i powagi sytuacji oraz ekspresyjności wypowiedzi. Dosyć liryczne i miłe określenia, takie jak „,krzta”, „,okruch”, „drobina” czy sentymentalna (i potęgująca wrażenie intymności) „poduszka w myszki mickey", ustępują stopniowo „,trzepnięciu w potylicę ciosem na odlew", ,"wrakowi", „ruinie”, ,"grypom", ,tryprom”, by zrobić w końcu miejsce „"kuli" niosącej śmierć.

\section{ASPEKTY UMIERANIA}

Wyjęte jakby z innej rzeczywistości jest kończące utwór stwierdzenie: „aniele: nie ma już światła które byłoby moim”. Warto tutaj przypomnieć konkluzję zamykającą Meskalinę: „Nie ma sensu pisać gdy duch nie prowadzi”. Jakże zaskakująco zbieżne są wnioski, do jakich dochodzą poeci! Czyż nie są to dwa warianty tej samej puenty, która podważa sensowność dalszej wegetacji w ciele pozbawionym anima? Człowiek, jako ontyczna jedność, w obliczu cielesnego obumierania jawi się kaleka, którego „niecielesna” sfera cierpi równie mocno. Ginsbergowski duch, który już nie prowadzi oraz powellowskie światto, które jest już tylko odbitym, to prawdziwa esencja cierpienia podmiotów obu wierszy.

Michel Guiomar w pracy Zasady estetyki śmierci ${ }^{73}$, usiłuje opisać pejzaż śmierci za pomocą trzech kategorii metafizycznych: demoniczności, apokaliptyczności i piekielności, przy czym rozumie je kolejno jako (w uproszczeniu): diaboliczność lub przejawy demonizmu psychicznego; świetliste objawienie tego, co poza śmiercią oraz dobrowolne uznanie prymatu wiecznego Cienia. Uniwersalizm tego podziału pozwala odnaleźćjego przejawy w postawach podmiotów lirycznych Meskaliny i [skarbie czy mnie udusisz...]. Demoniczność gnijacego Ginsberga i chorującego na AIDS mężczyzny można by wówczas rozgraniczyć na oba warianty: diaboliczność (w każdym z przypadków byłaby to kwestia ciała i jego rozkładu) oraz antagonizm dwóch sprzecznych temperamentów, jak nazywa to M. Guiomar - tragiczną grę wewnętrznej dwoistości. U Ginsberga byliby to, symbolicznie: Człowiek od Maszyny do pisania kontra człowiek ziemski i ludzki, konfrontujący się z seksualnościa, cielesnościa, tandeta umystu; u Powella: przywiązanie do życia, wyrażające się w tworzeniu własnego kosmosu z myszka mickey, skarbem, w zderzeniu ze pragnieniem śmierci wynikającym ze strachu. Apokaliptyczność w Meskalinie przedstawiona została w sposób dosłowny, w wizjach nowych narodzin, widzeniach czasu, Boga i śmierci; wiersz Powella jest zaś pod tym względem specyficzny - nie ma w nim pragnienia śmierci służącego poznaniu tego, co następuje po niej, a jedynie chęć uniknięcia tego, co tę śmierć przybliża, bezbolesnego przekroczenia progu odczuwania. Ostatnia kategoria, piekielność, przysporzyć może najwięcej problemów z odniesieniem jej do utworów. To konstrukcja filozoficzna złożona i niezwykle wieloaspektowa. Bohater i podmiot Meskaliny jest jej osobową realizacja, ze swoją kornością (choć nieraz buńczuczną) i uznaniem absolutnej większości „,Śmierci w Śmierci” (określenie Guiomara). Pojmowanie Śmierci przez pragnącej jej ofiary AIDS jest samo w sobie najlepszym aktem uznania i pochwały: dokonuje się w nim całkowita afirmacja mocy wybawczej, dostrzeżenie wielkości i niewyobrażalnej siły. Śmierć to kategoria metafizycznie pożądana nawet wtedy, gdy pragnie się jej tylko ze względów czysto estetycznych; gdy prosi się o nią żałośnie, z niecierpliwością oraz gdy pragnie się jej dumnie, ze strachu przed upokorzeniem.

Znamienne są słowa Thomasa Stearnsa Eliota z Wydrązonych ludzi, tak dobrze komponujące się z analizowaną poezja:

„I tak się właśnie kończy świat

I tak się właśnie kończy świat

I tak się właśnie kończy świat

Nie hukiem ale skomleniem ${ }^{\prime \prime 7}$

73 M. Guiomar, Zasady estetyki śmierci, [w:] S. Rosiek (red.), Wymiary śmierci..., dz. cyt., s. 77-94.

74 T. S. Eliot, Wydrazeni ludzie, Cz. Miłosz (thum.), [w:] ...opiewam nowoczesnego czlowieka. Antologia poezji amerykańskiej, Warszawa 1992, s. 125. 


\section{BibliografiA:}

[1] Białostocki J., Płeć śmierci, M. Ogonowska (red.), Gdańsk 2007.

[2] Brach-Czaina J., Metafizyka mięsa, [w:] M. Szpakowska (red.), Antropologia ciała, Warszawa 2008.

[3] Butler J., Złożoność kulturowej płci i granice identyfikacii, [w:] Butler J., Uwikłani w płeć. Feminizm i polityka tożsamości, Warszawa 2008.

[4] de M'Uzan M., A.j.j.m., [w:] S. Rosiek (oprac.) Wymiary śmierci, Gdańsk 2002.

[5] Ginsberg A., Meskalina, [w:] A. Ginsberg, Kadysz i inne wiersze, Musiał G. (thum.), Bydgoszcz 1992.

[6] Ginsberg A., Kadysz i inne wiersze, Musiał G. (tłum.), Bydgoszcz 1992

[7] Ginsberg A., Utwory poetyckie, Baran B. (tłum.), Kraków 1984.

[8] Ginsberg A., Znajomiz tego świata, Kraków 1993.

[9] Guiomar M., Zasady estetyki śmierci, [w:] S. Rosiek (oprac.), Wymiary śmierci..., Gdańsk 2002

[10] Kirsch H. C., W drodze. Poeci pokolenia beatników, J. Raczyńska (tłum.), Warszawa 2006.

[11] Kitliński T., Leszkowicz P., Homotekstualność: homoseksualność i twórczość, „Sekcja” 2005, nr 12

[12] Musiał G., Żelazne regimenty mody, [w:] Ginsberg A., Kadysz i inne wiersze, Musiał G. (tłum.), Bydgoszcz 1992.

[13] Powell D. A., Moim Wergiliuszem było wyzwanie, [w:] M. Tabaczyński (tłum. i red.), Parada równości. Antologia wspótczesnej amerykańskiej poezji gejowskiej ilesbijskiej, Kraków 2005.

[14] Powell D. A., [skarbie czy mnie udusisz: poduszką w myszki mickey], [w:] Powell D. A., Parada równości. Antologia wspótczesnej amerykańskiej poezji gejowskiej i lesbiiskiej, Kraków 2005.

[15] Shusterman R., Świadomość ciała. Dociekania z zakresu somaestetyki, Małecki W., Stankiewicz S. (tłum.), Kraków 2010.

[16] Sommer P., Ten staroświecki Allen Ginsberg, [w:] Ginsberg A., Znajomi z tego świata, Kraków 1993. 